\title{
Importance and Influence of Interest Groups in Welfare Policymaking Processes - Seen Through Citizens' Lenses- the Case of North Macedonia
}

\section{Elisabeta Bajrami Ollogu}

Lecturer at the Faculty of Social Sciences, Mother Teresa University in Skopje, North

Macedonia

\section{Abstract}

This paper aims to explore the influence of interest groups regarding social welfare policies implemented in North Macedonia and analyze how this influence is perceived through citizens' lenses. Considering the importance of interest groups in democratic systems where principles of good governance should be implemented, it is of main importance to explore at what extent interest groups contribute or affect processes of policy-making. What are some interest groups that can be considered as influential and have the highest levels of membership referring to social policies? How do citizenbeneficiaries perceive current Macedonian welfare state and what is their perception regarding the role of interest groups in pushing policy processes? The purpose of the paper is to explore associations that aim to protect public interest and influence decision making as much as groups serving narrow interests in the field of social policy. There is increasing recognition of the emergence of new and pernicious interest groups, which have influence on policymaking. Methodologically, this research is designed based on a desk research, literature review and empirical research, conducted in the period of October 2019 - March 2020. The perceptions are being measured through questionnaires that have been conducted with random individuals (beneficiaries/not beneficiaries of social services) with the aim to have some insights on behalf of their perceptions regarding the welfare/social protection system and additionally have some evidence of their participation in interest groups as well. The results of this research show low levels of participation and trust of citizens in interest groups and little contentment regarding welfare policies and delivery of social services, in the country.

Keywords: Interest groups; North Macedonia; Welfare; Perceptions 


\section{Introduction}

Groups of interest, in contemporary societies, represent a significant motor of development due to the pressure they persistently make on pushing political processes or broadly influencing public bodies in applying in their governances such principles as: justice; equality; equity; inclusion etc. There are some definitions of what interest groups represent. Broadly seen, they are mostly considered as associations of individuals or organizations which on the basis of one or more shared concerns, attempts to influence public policy in its favor usually by lobbying members of the government.

Interest groups are particularly significant at a national level. Increasing in size, governments seem like becoming more detached from their citizens, making it more difficult for officials or institutions to respond to citizens' real needs. On the other hand, citizens often find it difficult to navigate large government structures in order to effectively lobby for changes affecting their lives. NGOs and specific interest groups seem to have the expertise to open governments to their citizens. Interest groups may improve policy-making by providing valuable knowledge and insight data on specific issues. The civil society sector fills this gap by mobilizing citizens into larger groups led by professional representatives. These individuals have the practical knowledge of how to penetrate layers of government more effectively than a single person would. They provide the people around them with a comprehensive and coherent form of government approach, but also act as a bridge between the citizen and the government. Moreover, as issues dealt with by the government become more and more complex, they should be assisted by experts offer professional advices on how to better act in certain situations. These organizations are full of individuals with expertise in their field that can advise leaders on the practical impact of certain policy decisions. For individuals who want to set up membership groups, it is important to understand what makes one organization more successful in seeking change than the other. Unfortunately, there is still no good culture of membership in civil society in North Macedonia, as long as the interests of small and better-organized groups rule the public interest.

On the other hand, there is also evidence that lobbying and interest groups can negatively influence policy-making, due to their orientation or representing interests negatively affecting democratic processes. In addition, Campos and Giovannoni (2008) have shown that in transition countries, interest groups influence through lobbying is found to be an alternative instrument of political influence vis-à-vis corruption. In this context, their findings are that lobbying, if adequately regulated, is a much more effective instrument than corruption for exerting political influence and that lobbying is also a much stronger explanatory factor than corruption for firm performance. In this context, in order to avoid the negative impacts of interest group influence on policy measures, full transparency is essential. Therefore, a broad range 
of regulations should be established depending on the country's political environment and state of development (Zinnbauer, 2009).

In the case of North Macedonia, the regulation of most associations is provided through the "Law for Associations and Foundations"1. Under article 11 of the law, is stipulated the following: "The organization's activity is public", and in article 12 of the law: "Publicity of the organization's activity is realized through transparent publication of the statute and other acts of the organization, in accordance with its statute". 2 Moreover, different economies have adopted various regulations with the aim to prevent the negative influence of interest group on policy-making, ranging from lobbying and conflict of interest regulations to access to information laws.

\section{Social Policy directions - importance of lobbying concerning social policy}

There is very little research on interest group influence on policy-making and its potential benefits. When it comes to the influence of interest groups in the field of social policy the data is even more evasive. Nevertheless, there is some evidence that civil sector and other organizations have pushed policy-making processes, in particular for disabled people, children with special needs and workers' rights. Even the membership is mostly oriented in these type of organizations. This might have been determined due the fact that in North Macedonia, most of interest groups include human rights groups, women's groups and environmental groups, as well as NGOs active in the areas of good governance and democratization. According a research made by Cekik, A (2015) "The large majority of NGOs were formed after the introduction of political pluralism in the 1990s, while some trade unions, chambers of commerce and professional associations existed during socialism. Today, pluralism in the area of trade unionism and business associations is allowed and their interests are typically represented by several national-level umbrella associations"3. Social welfare/social security, local and regional development and employment policy also attract a considerable amount of lobbying.

It might be highlighted the fact that during the transition period of the country, there have been lots of initiatives which aim to increase debates between actors involved, regarding the crucial role of interest groups towards influences in policy making processes. Governments cannot act by their own since they are strongly connected to other organization outside of governmental institutions. In this regard, in democratic countries where good governance principles are being developed, the relationship between the state (government), political parties in opposition and other groups of interest must be intense. It is a sign that democratic system is in the right pathway. The transition to liberal democracy and the ongoing EU accession process frame the

\footnotetext{
1 Закон за здруженија и фондации бр.52, 2010. www.slvesnik.com.mk

2 Закон за здруженија и фондации, article 11, 12, 2010, pg. 15

${ }^{3}$ Cekik, A., Lobbying by interest groups in Macedonia, Montenegro and Serbia: findings from a survey of associations, 2015, pg. 2
} 
national context of the system of interest representation (Fink-Hafner, 2015; Hristova and Cekik, 2015). When it comes to public policy influences, think tanks are important as well. In the context of policies, a 'think tank' represents an organization of independent but they themselves can also take initiatives in this regard with the aim of influencing public policy ${ }^{1}$.

Unfortunately, there is still no good culture of membership in CSOs in North Macedonia, as long as the interests of small and better-organized groups rule the public interest. Previous studies have also shown that the extent of lobbying increases with income, and that firms belonging to a lobby group are significantly less likely to pay bribes. On the other hand, in politically less stable countries, firms are more likely to bribe and less likely to join a lobby group (Campos, Giovannoni, 2006).

On the other hand, one of the barriers while influencing the welfare system is related to transparency. Interest group influence may also depend on the salience of an issue - 'the more attention the public pays to a specific decision; the more difficult it should be for a special interest group to influence the outcome'2. In this context, governments should encourage citizens' participation, facilitating (or making mandatory) open hearings on policies and consultative decision-making processes (Transparency International, 2009).

\section{Methodology}

Methodologically this research paper is a combination of literature review and empirical data analysis, conducted in the period of October 2019 - March 2020. Primary data is collected through survey and this is a questionnaire-based survey, which means that the citizens' perceptions are being measured through a questionnaire which has been conducted online. The online questionnaire was conducted in order to gather large size of information in a short period. The questionnaire is designed by using multiple-choice questions in which respondents could select one or more options from a list of answers defined and it is divided in two main sessions.

\subsection{Sampling}

The questionnaire was conducted using the random sampling technique, under which, each member of the population had an equal opportunity of being chosen as a part of the sampling process. In this case, the research was conducted with random citizens (beneficiaries/not beneficiaries of social welfare system) who represent a larger population for whom the results can be generalized. The advantages of the simple random sample in this case include its ease of use and its accurate representation of the larger population. Samples are used in statistical testing, even

\footnotetext{
1 Simon, James. The Idea Brokers: The impact of Think Tanks on British Government, Public Administration, 1993, pg. 492

2 Dur, A.; Bievre, D., The Question of Interest Group Influence. International Public Policy, 2007, pg.8
} 
though the number of population here is less than $10 \%$ of total population. Further stratification by including most convenient characteristics of population, will be applied in next steps of this research.

\subsubsection{Demographic data:}

Total number of respondents: $\quad 50$

Median age: 29

Gender:

22 female

28 male

Education level

24 Bachelor degree

Employment status

21 High school degree or equivalent

5 Less than high school degree

33 Employed, working 1-39 hours per week

5 Employed, working 40 or more hours per week

12 Not employed, looking for work

0 Not employed, NOT looking for work

0 Retired

0 Disabled, Not able to work

Taking into account the typology of the research, main demographic characteristics of the population refer to the following: the median age, which results to be about 29 years old, regarding gender the dominant data refers to males. On behalf of education level almost half of respondents have tertiary education and there are other 21 with high school degree or equivalent; regarding employment status there are 33/50 and $5 / 50$ citizens who have the status of employees and others who are not employed but looking for work.

\section{Findings}

The aim of the research is to have some evidence related to citizens' perceptions regarding welfare system (overall impressions) and at least have some evidence regarding interest groups and eventual membership in these interest groups. The system of social protection and social insurance in the Republic of North Macedonia is a set of many rights and services in the field social protection, 
employment/unemployment, child protection, social insurance, disability insurance, health insurance. The findings here refer to the results of a questionnaire applied to 50 random citizens in the region of Skopje, by not identifying perceptions in a specific social policy domain but in all above-mentioned domains. Additionally, in a second session, citizens' perceptions are being collected regarding interest groups and their influence in policy-making processes by addressing citizens' needs.

\subsection{Session I: General perceptions towards welfare state and social services}

\subsubsection{Perceptions regarding social policy as a government mechanism}

\begin{tabular}{|l|l|}
\hline \multicolumn{2}{|l|}{ What do you think social policy refers to: } \\
\hline Electoral politics & $2 \%$ \\
\hline Policies of poverty reduction & $14 \%$ \\
\hline Employment policies & $21 \%$ \\
\hline Social protection & $30 \%$ \\
\hline Taxation policies & $1 \%$ \\
\hline Social insurance & $13 \%$ \\
\hline I have no idea & $19 \%$ \\
\hline
\end{tabular}

Tab. 1

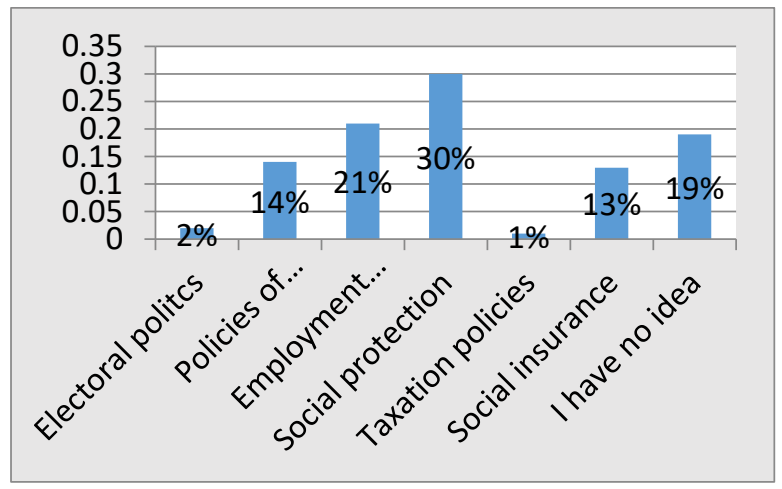

Obviously some of the respondents have no clear information of what social policy represents, affiliating it even with electoral politics or taxation policies. Despite that, most of the respondents, around $30 \%$ perceive it is related directly to social protection system and $21 \%$ relate it with employment policies. A significant result refers to the $14 \%$ of the respondents, who affiliate social policy with policies of poverty reduction, an indicator that indicates for a more thorough assessment in 
further research. At least, it is quite disappointing the fact $19 \%$ of respondents is unfamiliar with the answering. It is worrying that the youngest is in the same time most uninformed population (considering that the median age of respondents is around 29 years old).

\subsubsection{Perceptions regarding social services}

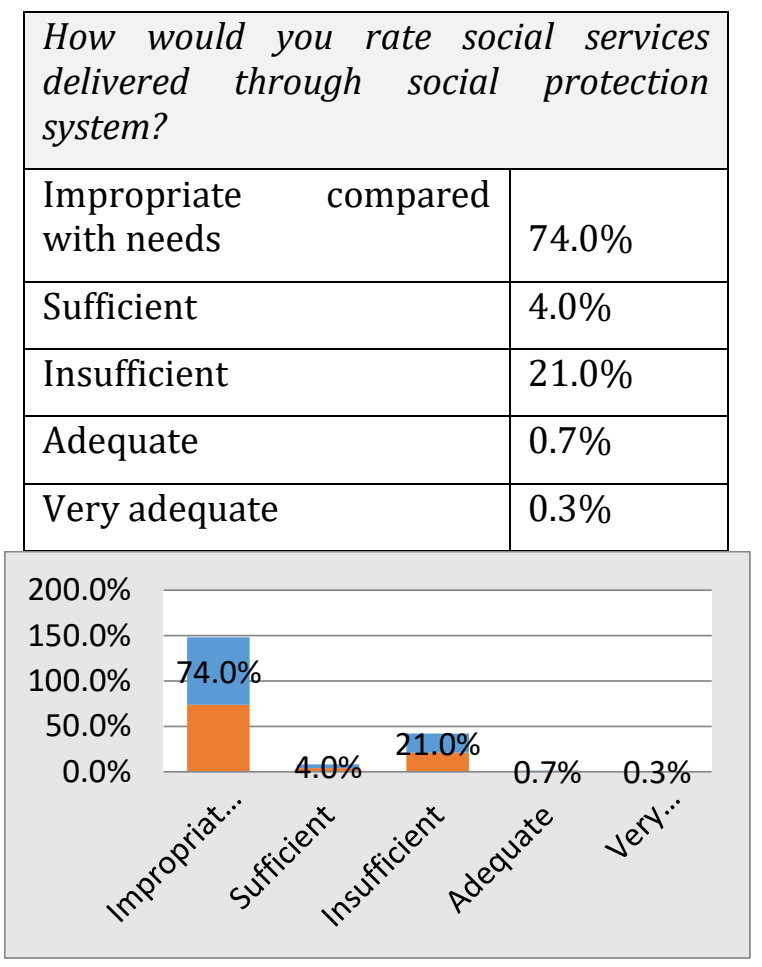

Tab. 2

The respondent's perception regarding social services delivered through social protection system shows their disappointment in terms of quantity. According to them, most of services delivered (not specified whether they are financial or not) don't usually meet identified needs and most of them think they're insufficient. Only $0.3 \%$ of respondents consider social services as very appropriate. One explanation of this result can be the fact they may perceive social services as related in particular with financial social assistance. A second explanation might be the fact that respondents refer to social services only to those offered through centers of social work. This is why, in the next question they were asked whether is there any domain perceived as more important. 


\subsubsection{Perceptions regarding social policy domains}

\begin{tabular}{|c|c|}
\hline \multicolumn{2}{|c|}{$\begin{array}{l}\text { What are most important fields in which } \\
\text { social protection and insurance system } \\
\text { must be focused? }\end{array}$} \\
\hline Employment & $28.0 \%$ \\
\hline Social protection & $24.0 \%$ \\
\hline Social Assistance & $25.0 \%$ \\
\hline Health insurance & $8.0 \%$ \\
\hline Child Protection & $11.0 \%$ \\
\hline $\begin{array}{l}\text { Pensions \& disability } \\
\text { insurance }\end{array}$ & $4.0 \%$ \\
\hline
\end{tabular}

Main perception identified here is that citizens consider as most important domain, employment. This can be explained with the fact that most of households' incomes rely on wages and the perception that social policy is increasingly directed towards stimulating employment in broader sections of society. Around $25 \%$ of the respondents consider social assistance as the second most important domain. Once again, this is directly related with their perception of social risk and social welfare based on the principle 'minimal income for minimal welfare'. Most underrated domain is seen the one related with pensions and disability insurance. This can be explained due the sample of respondents whose median age results 29 years old and there may be no concern yet about the pension systems or need for disability pensions. This would also need further assessment by involving a larger number of citizens, in order to have a more significant and objective result.

\subsubsection{Perceptions regarding improvements of social services' delivery}

\begin{tabular}{|l|l|}
\hline \multicolumn{2}{|l|}{$\begin{array}{l}\text { In your opinion, what are most obvious problems when } \\
\text { receiving social services? }\end{array}$} \\
\hline Too much bureaucracy in institutions & $28.0 \%$ \\
\hline Incompetent professionals & $42.0 \%$ \\
\hline Difficulty accessing social services & $17.0 \%$ \\
\hline $\begin{array}{l}\text { Corruption while attempting to benefit social } \\
\text { rights }\end{array}$ & $13.0 \%$ \\
\hline
\end{tabular}

As seen from the above results, main perception of citizens is related with two major problems while receiving social services or applying for them to be delivered: on one hand the incompetence of professionals working in the respective institutions and on 
the other hand the amount of procedures or summarized as bureaucracy ${ }^{1}$ in these institutions. In this regard, a previous research from Gerovska Mitev, M (2017) affirmed more in detail the citizens' complaints: "According to the perceptions of the citizens, the public image of the institutions from social protection, especially to nursing homes and centers for social work is negative. Negative perceptions are prominent and in relation to access to the right to social financial assistance, while for social services and parental compensation for the third child perceptions are divided ${ }^{2}$.

Evidently, comparing the results, it might be generalized that the citizens' complaints towards institutions and their staff are persistent in the last years. The only difference to discuss here is that in the above mentioned research are assessed separately different perceptions on different domains and the result refers more in specific to services delivered through centers for social work. According to the same study: one possible way to achieve greater transparency and accountability is ensuring public access to the scope, forms and profile of users using rights and services through social work centers. This approach will be useful for affirming situations at the local level as well and for stakeholders who can take advantage of this information, in support of social work centers or vulnerable categories, with additional forms of support ${ }^{3}$. What in fact stresses in our current research is the surprising positive perception regarding eventual corruption while attempting to benefit social rights which has the lowest percentage. Obviously, citizens do not consider it an emerging problem compared to other options.

\subsubsection{Overall perceptions regarding welfare state in North Macedonia}

\begin{tabular}{|l|l|}
\hline $\begin{array}{l}\text { How would you rate welfare state in North } \\
\text { Macedonia? }\end{array}$ \\
\hline Minimalist welfare state & $48 \%$ \\
\hline Improved in the last decade & $1 \%$ \\
\hline There's no welfare state in N.M & $28 \%$ \\
\hline In transition & $16 \%$ \\
\hline Developed & $7 \%$ \\
\hline
\end{tabular}

${ }^{1}$ Bureaucracy refers to both a body of non-elected government officials and an administrative policymaking group.

2 Gerovska Mitev, M., (2017). Извештај за перцепциите на граѓаните за правата и услугите од социјална заштита и социјално осигурување, Центар за управување со промени, http://www.cup.org.mk/publications/Socijalna-zastita_f.pdf , pg. 26-27

3 ibid, pg. 29 
Tab. 5In this final question, citizens were asked to evaluate somehow the social welfare state developed in the country. As seen above, $48 \%$ of the respondents perceive it as minimalistic. This means they see it as provider of basic social rights and not able to fulfill social needs. On the other hand, around $28 \%$ of the respondents are totally skeptics about the existence of the welfare state itself. This skepticism towards welfare state can be explained as the people's complaint for their needs not being fulfilled, as they expect the state to be responsible in all policy areas. The welfare rights idea is perceived as the view in which persons are seen as ends in themselves and the key role of the government is the protection and promotion of the economic and social well-being of its citizens.

\subsection{Session II: Membership and perceptions related to interest groups}

\subsubsection{Membership in interest groups}

\begin{tabular}{|l|l|}
\hline Are you currently member of any association? \\
\hline Yes & $2 \%$ \\
\hline No & $77 \%$ \\
\hline Never been interested & $8 \%$ \\
\hline Looking forward to & $13 \%$ \\
\hline
\end{tabular}

As it's seen from the results, only $2 \%$ of the respondents are currently members of an association and around 77\% aren't, which shows that there is still no good culture of membership in the civil society sector in North Macedonia. Public support for interest groups seems to be at a low level and citizens do not perceive them as supporter of addressing citizens' social problems and needs or promoting social rights. A very interesting data refers to the fact that around 13\% of the respondents would be interested to join any of the associations in the future which confirms the need of interest groups to become more visible and accessible for citizens of all ages, social statuses, etc.

\subsubsection{Main typologies of membership}

\begin{tabular}{|l|l|}
\hline \multicolumn{2}{|c|}{ If "yes", would you indicate the typology of association? } \\
\hline Trade union & $1.2 \%$ \\
\hline Citizen association & $0.2 \%$ \\
\hline Business association & $0.3 \%$ \\
\hline Professional association & $0.2 \%$ \\
\hline Think tank & $0.0 \%$ \\
\hline Foundation & $0.1 \%$ \\
\hline Chamber of Commerce & $0.0 \%$ \\
\hline Other (....) & $0.0 \%$ \\
\hline
\end{tabular}


According to data provided through desk research, currently there is an available list of associations and umbrella organizations operating in the country. ${ }^{1}$

Around $1.2 \%$ of those $2 \%$ who answered 'YES', affirm their membership in trade unions as the prevalent interest group identified in this research. Business associations and citizens' associations have more or less similar shares of the total number of interest groups. This finding suggests that the populations of interest groups in the last years are rather dynamic and that the number of organizations which appear and then cease to operate after a short period of time might be rather high. Almost none of the respondents are familiar with think tanks, which from secondary resources results to be mostly active in the monitoring of national political developments. Besides alternatives, two of the respondents list as other associations those related in concrete activities, which refer to organizations operating in the field of youth activities. This result can be explained due the median age of the respondents, which is at around 29 years old and they can eventually be taking part in organizations related to their universities, youth community centers, etc.

\subsubsection{Perception of interest groups importance}

\begin{tabular}{|l|l|}
\hline \multicolumn{2}{|l|}{$\begin{array}{l}\text { At what extent, you think, interest groups influence social policy-making } \\
\text { processes: }\end{array}$} \\
\hline Minimal influence & $31 \%$ \\
\hline Only in some issues & $18 \%$ \\
\hline Very influential & $35 \%$ \\
\hline Absolutely not & $8 \%$ \\
\hline Somehow & $8 \%$ \\
\hline
\end{tabular}

Even though previous data on this research showed low levels of citizens' membership in various interest groups, most of the respondents agree that interest groups are important and consider them as influential. But, in which fields they would support the public is an issue which requires further assessment. From the current results it's obvious a $31 \%$ of respondents who are skeptic regarding the extent in which interest groups would influence policy making processes. They are skeptic towards the role of interest groups in monitoring and keeping the government accountable to the public interest.

${ }^{1}$ According TACSO website, there are listed 126 citizen associations in Macedonia; Macedonian Centre for International Cooperation lists 243 (mostly local) associations;

According the Ministry of Labour and Social Policy there are 48 umbrella and branch trade unions in total 


\section{Conclusions}

From the results of this survey, it is evident that most of citizens do not have enough information about associations operating as interest groups. This is why associations/NGOs should design programs and platforms involving as many members as possible in order to make their interests as attractive as possible to citizens and then to political representatives. This is of main importance due the fact that CSOs should decrease this gap (between state and citizens) by mobilizing citizens into larger groups led by professional representatives. The results showed there is still no good culture of membership in civil society in North Macedonia, as long as the interests of small and better-organized groups rule the public interest. As previously found in other studies, citizen participation in associations in these countries is still lower than that in Western democracies and Central European countries (Novak and Hafner - Fink, 2015) ${ }^{1}$.

The respondent's perception regarding social services delivered through social protection system shows their disappointment in terms of quantity. According to them, most of services offered (not specified either they are financial or not) do not meet usually identified needs and most of them think they are insufficient. Main perception identified here is that citizens consider as most important domain employment. They see social policy as increasingly directed towards stimulating employment in broader sections of society. Most underrated domain is seen the one related with pensions and disability insurance. Main complaint perceived from citizens about the quality of social services delivering is seen related with incompetence of professionals working in the respective institutions on one hand and on the other with the amount of procedures or summarized as bureaucracy in these institutions. There is skepticism towards welfare state in general. The welfare rights idea perceived as the view in which individuals are seen as ends in themselves and the key role of the government is the protection and promotion of the economic and social well-being of its citizens. Nevertheless, there is evident lack of contentment regarding social services delivered through social protection system and overall welfare state idea.

Regarding perception related to interest groups: although the results above presented reflect low levels of citizens' membership in various interest groups, most of them agree that interest groups are important and consider them as influential. Nevertheless, in which fields they would support the public is an issue, which requires further assessment. Business associations and citizens' associations have more or less similar shares of the total number of interest groups. This finding suggests that the populations of interest groups in the last years are rather dynamic and that the

1 in Cekik, A. Lobbying by interest groups in Macedonia, Montenegro and Serbia: findings from a survey of associations, 2015, pg.5 
number of organizations, which appear and then cease to operate after a short period, might be rather high.

As a final remark, citizens in beneficiary's position prefer improved social services delivered beyond the general preferences they express when endorsing a party's platform and electing parliamentary representatives or participating in various groups. They want public bodies to take in account their voice and interest groups seem to be citizens' mechanism to address their issues, while social policies are the governments' mechanisms to respond citizens' needs. An emerging need to renegotiate the relationship between the parties and increase the dialogue is evident.

\section{References}

[1] Campos, N., Giovannoni, F., (2008). Lobbying, Corruption and other Banes. IZA DP n. 3693 Discussion paper series. http://ftp.iza.org/dp3693.pdf

[2] Campos, N. and F. Giovannoni., (2006). Lobbying, Corruption and Political Influence, Public Choice

[3] Campos, N., (2009). In pursuit of policy influence: Can lobbying be a legitimate alternative to corruption in developing countries? U4 Anti-Corruption Resource Centre Brief

[4] Cekik, A., (2015). Lobbying by interest groups in Macedonia, Montenegro and Serbia: findings from a survey of associations. Erasmus Mundus publication

[5] Dur, A.; Bievre, D., (2007). The Question of Interest Group Influence. International Public Policy

[6] Fink-Hafner D. (2015). A framework for studying the development of civil society on the territory of the former Yugoslavia since the 1980s. In Fink-Hafner D. (ed.) The development of civil society in the countries on the territory of the former Yugoslavia since the 1980s. Faculty of social sciences, University of Ljubljana.

[7] Gerovska Mitev, M., (2017). Извештај за перцепциите на граѓаните за правата и услугите од социјална заштита и социјално осигурување, Центар за управување со промени http://www.cup.org.mk/publications/Socijalna-zastita_f.pdf

[8] Novak M. and Hafner-Fink M. (2015) Social participation, political participation and protests on the territory of former Yugoslavia: comparative view based on social survey data. In Fink-Hafner D. (ed.) The development of civil society in the countries on the territory of the former Yugoslavia since the 1980s. Faculty of social sciences, University of Ljubljana.

[9] Simon, James., (1993) The Idea Brokers: The impact of Think Tanks on British Government, Public Administration 
[10] Zinnbauer, D., 2009. The role of investors in strengthening corporate integrity and responsibility in Global Corruption Report: Corruption and the Private Sector in Transparency International, The global coalition against corruption: CMI (CHR MICHELSEN INSTITUTE)

[11] Transparency International, 2009. Controlling Corporate Lobbying and Financing of Political Activities. Policy Position 6/2009.

[12] Закон за здруженија и фондации бр.52, 2010. www.slvesnik.com.mk 